\title{
Type I collagen cross-linked N-telopeptide および
}

\section{Type I collagen cross-linked C-telopeptide による乳癌骨転移評価}

\author{
和歌山県立医科大学第 1 外科 \\ 尾 浦 正二内藤 泰 顕
}

骨転移ないし骨浸潤を有する女性乳癌患者30例を対象に Type I collagen cross-linked N-telopeptide (NTx) の骨転移診断能を Type I collagen cross-linked C-telopeptide（I CTP） と比較検討した. NTx およびI CTP は，共に骨病変個数が増加する につれ高值を示したが, 骨病変個数との相関は I CTPの方が良好であった. NTx およ び I CTP は, 乳癌術後非担癌患者に比較して骨病変を有する症例で高值を示したが, 骨 病変陽性例で cut off 值以上を示す割合は, NTxが16.7\%であったのに対し，I CTPで は56.7\%であった，また骨病変が良好に制御されている症例と制御不良な症例を比較す ると, I CTP では後者が前者の 2 倍, NTxでは1.7倍の值を示した.しかしながら NTx においては, 骨病変の制御不良症例でも平均値が cut off 以下であった. 以上より, 乳癌 骨病変診断能は, NTxよりもI CTPの方が優れていると思われる。

卖引用語: 乳癌, 骨転移, I CTP, NTx

\section{はじめに}

各種悪性腫湯の転移・再発診断扝よび治療効果の判 定は，画像診断と腫場マーカーが重要な役割を果たし てきた。一方，骨粗僰症を主たる対象疾患として開発 されてきた骨代謝マーカーが骨転移の診断および治療 効果の判定に有用であることが認識され，骨転移診断 にも用いられるようになってきている。しかしながら， 骨代謝マーカーの骨転移への臨床応用は, 未だ臨床の 端緒についたばかりであり、これまでに開発された 種々の骨代謝マーカーの臨床的意義に関しても不明な 点が多い.

今回著者らは, Erye らが開発した type I collagen cross-linked N-telopeptide (NTX) ${ }^{122}$ の乳癌骨転移に 対する臨床的意義を type I collagen cross-linked C -telopeptide $(\mathrm{I} \mathrm{CTP})^{3 / 4)}$ と比較検討したので報告す る.

\section{対象および方法}

骨転移を有する女性乳癌患者 30 例（2 例は，骨浸潤 例)を対象とした，対象症例の背景因子を表 1 に示す。 年龄は33-76歳 (中央值55歳)であり, 多発骨転移, 癌 性骨疼痛および骨外活動性病変をそれぞれ13例が有し

1999年 7 月 26 日受付 1999 年10月14日採用
ていた。また任意に選択した乳癌術後非再発女性患者 43例 (NTx13例，I CTP30例) の尿中 NTx および血 中 I CTP レベルも併せて測定した。非再発例で NTx 測定を行った13例の年齢は36-71歳 (中央値52歳)であ り，I CTP 測定を行った 30 例の年歯は $36-81$ 歳 (中央 值52歳)であった。骨代謝マーカー測定時には，骨転 移例および非再発例の全症例に，再発治療ないし術後 補助療法がなされていたが, Iuteinizing hormonereleasing hormone の投与を行っている症例, 重複癌 を有する症例，腎機能障害を有する症例および治療を

表 1 背景因子

\begin{tabular}{|c|c|}
\hline 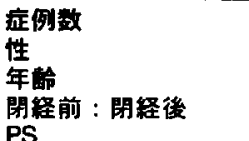 & $\begin{array}{l}30 \text { 例 } \\
\text { 全例女性 } \\
33-76 \text { 歳 (中央値54.5嵅) } \\
3 \text { 例 }: 27 \text { 例 (卵摘5 例を合む) }\end{array}$ \\
\hline 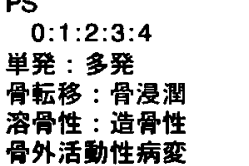 & $\begin{array}{l}11 \text { 例: } 15 \text { 例: } 2 \text { 例: } 2 \text { 例: 0例 } \\
17 \text { 例 }: 13 \text { 例 } \\
28 \text { 例 }: 2 \text { 例 } \\
29 \text { 例 }: 1 \text { 例 }\end{array}$ \\
\hline 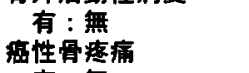 & 13 例: 17 例 \\
\hline $\begin{array}{c}\text { 有 : 無 } \\
\text { 骨病变の活動性 }\end{array}$ & 13例: 17 例 \\
\hline 制御：進行・增悪 & 17 例: 13 例 \\
\hline
\end{tabular}


要する骨粗䅗症を有する症例は，今回の対象には含め なかった。

採尿ならびに採血は共に午前10時頃に行い，それぞ れ尿および血清を測定までー20度で保存した。骨代謝 マーカーの測定は，1 CTPには Orion Diagnostica 社製の I CTP キット,NTxには Ostex International

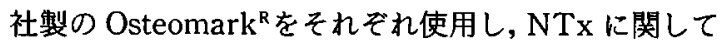
は,クレアチニン $(\mathrm{Cr})$ 補正を行った。測定方法は, I CTP が radioimmunoassay, NTx が enzyme-linked immunosorbent assay によった。骨転移に対する cut off 值は，1 CTP が4.5ng/mL，NTx が100nM $\mathrm{BCE} / \mathrm{mM} \mathrm{Cr}$ とした.

骨転移個数と骨代謝マーカーの相関の検討では，画 像上10個以上の転移は,転移個数を10個として処理し， Stat View J-4.5を用いて直線回帰分析を行った。 ま た, 骨病変の状態の判定に関しては, たとえ画像上著 明な変化を認めない症例でも癌性疼痛の継続的增悪を 認める場合には，進行・増覀症例に分類した。骨病変 陽性例と陰性例の骨代謝マーカーレベルの比較には $\mathrm{t}$ 検定を用い, $\mathrm{p}<0.05$ の場合を有意差ありと判定した. 結 果

1. 骨病变個数と骨代謝マーカーの相関 (図 1 )

骨病変個数が増加する程, 各骨代謝マーカーは, 高 值を示した. 直線回帰分析による決定係数は, I CTP が0.677で NTx が0.405であった。

2. 血清 I CTP 値について（図 2)

\section{$(\mathrm{ng} / \mathrm{mL})$}

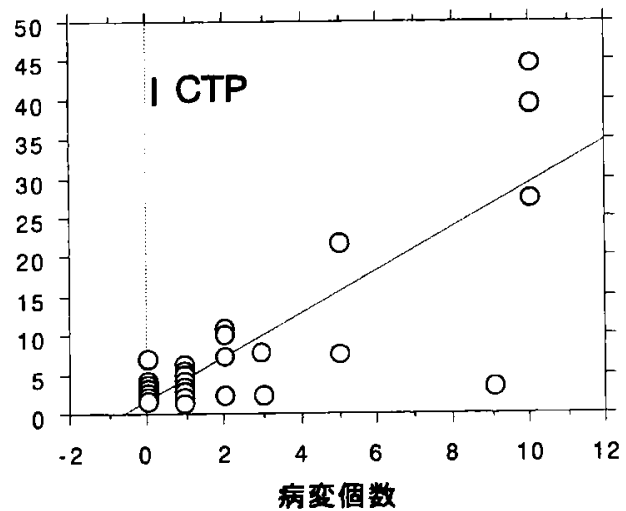

I CTP $=2.436+2.611 \times$ 病变個数 $P=0.677$
骨病変陽性例 $(n=30)$ の血清 I CTP 值の平均は8.7 $\mathrm{ng} / \mathrm{mL}$ であり, 骨転移陰性例 $(\mathrm{n}=30)$ の平均 (3.0ng/ $\mathrm{mL})$ よりも有意に高值を示した $(\mathrm{p}=0.0054)$ 。また骨 病変陽性例では，56.7\%（n=17）の症例で $4.5 \mathrm{ng} / \mathrm{mL}$ 以上を示したのに対し，骨転移陰性例では6.6\%（n=

2）の症例のみが異常高値を示した.

3 ，尿中 NTx 值について（図 3)

骨病変陽性例 $(\mathrm{n}=30)$ の尿中 $\mathrm{NT} x$ 值の平均は, 75 $\mathrm{nM} \mathrm{BCE/mMCr}$ であったのに対し, 骨病変陰性例 (n=13)では41nM BCE/mMCrであった（ $\mathrm{p}=$ 0.238)。また，骨病変陽性例では $16.7 \%(\mathrm{n}=5)$ の症 例が $100 \mathrm{nM} \mathrm{BCE} / \mathrm{mMCr}$ 以上の值を示したのに対し, 骨病変陰性例では，1例も異常高値を示さなかった。

4. 骨病変の状態と骨代謝マーカーについて (表 2)

種々の治療により骨病変が部分効果 $(\mathrm{PR})$ を示すか, 長期的に不変 $(\mathrm{NC})$ を維持している症例と進行·増悪 (PD)している症例とでは，NTx および I CTP の両 マーカーに扔いて有意差はないものの後者が高值を示 した。骨代謝マーカーの平均値は, I CTP では, 骨病 変の制御が不良症例において, 良好に制御されている 症例の 2 倍の值を示し, NTxでは1.7倍の高值を示し た。しかしながら, NTxでは, 骨病変の進行・増悪例 においても，その平均值は, cut off 值以下であった.

\section{考 察}

骨代謝マーカーは，骨形成マーカーと骨吸収マーカ 一に大別される ${ }^{5)}$. 骨形成マーカーは，主として骨粗鬆
(nM BCE/mM Cr)

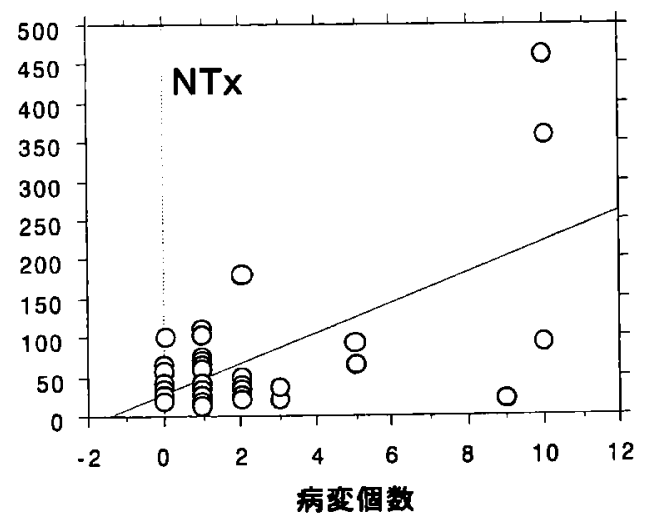

NTx $=27.699+19.379 \times$ 病落個数 $R^{2}=0.405$

図 1 骨病变個数と骨代謝マーカーの相関 
2 号

骨病変陽性 骨病变陰性

$(n=30)$

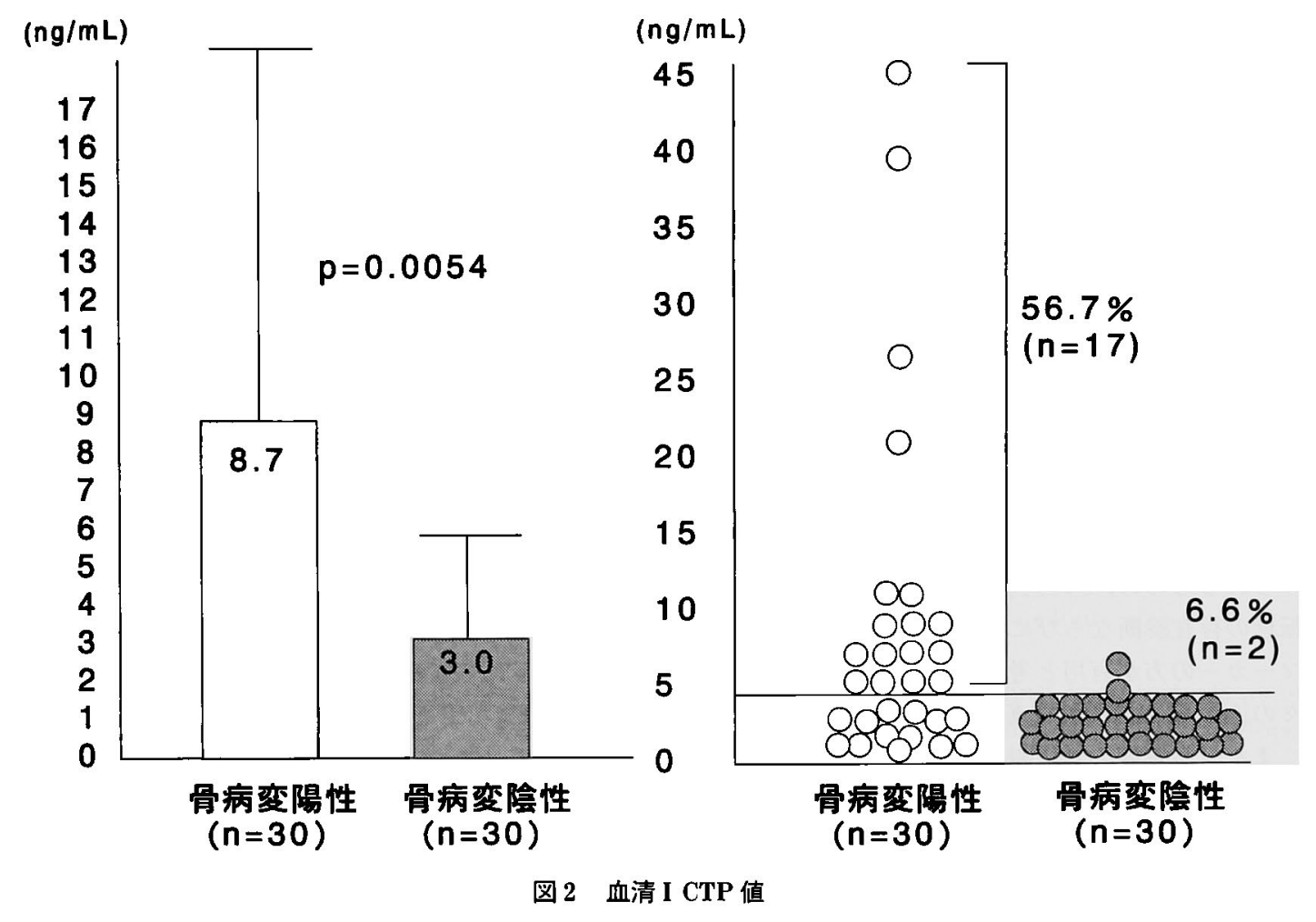

NTx およU゙I CTPによる乳癌骨枟移評価

(nM BCE/mM Cr)

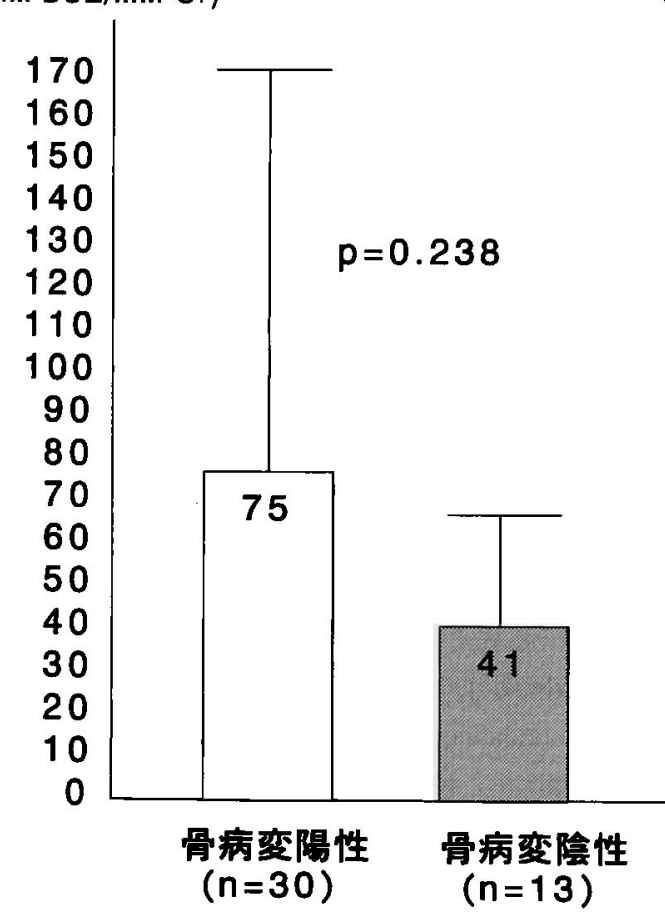

(nM BCE/mM Cr)

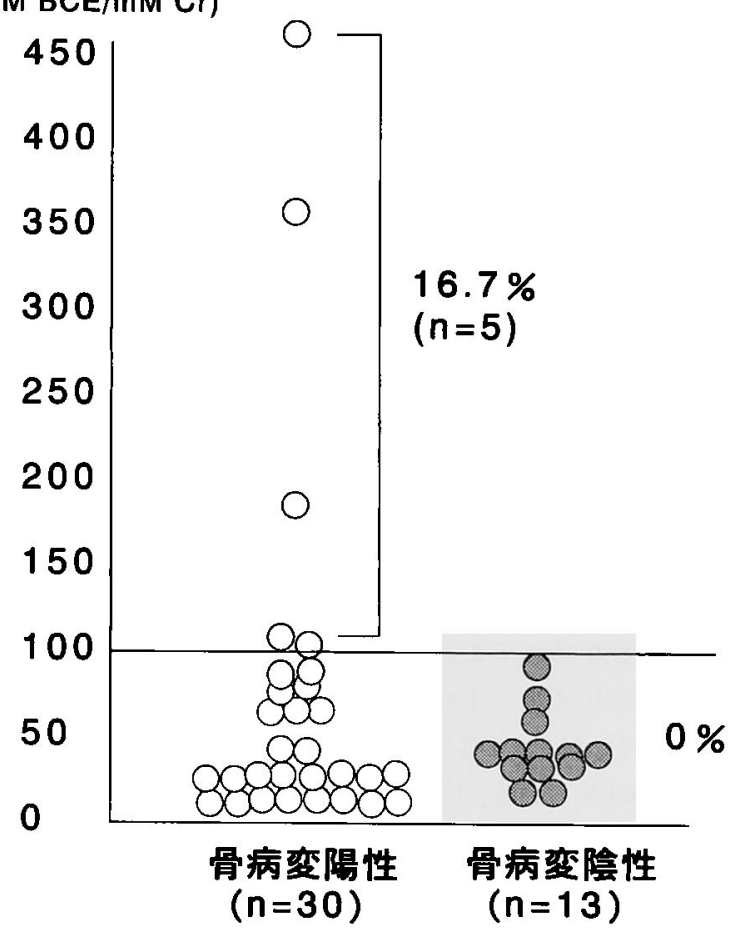

図 3 尿中 NTx 值 
表 2 骨病変の状態と骨代謝マーカー

\begin{tabular}{|c|c|c|c|}
\hline & 良好に制初 & 進行 - 㙁要 & p值 \\
\hline $\begin{array}{c}\text { 1CTP } \\
(<4.5 \mathrm{ng} / \mathrm{mL})\end{array}$ & $6.0 \pm 4.8$ & $12.2 \pm 14.9$ & 0.119 \\
\hline $\begin{array}{c}\text { NTX } \\
(<100 \mathrm{nM} \mathrm{BCE/mM} \mathrm{Cr})\end{array}$ & $58.1 \pm 44.9$ & $96.0 \pm 142.3$ & 0.308 \\
\hline
\end{tabular}

症等の良性骨疾思においてアンカップリング5(6)の状 態を判定したり，造骨型骨肉腫や前立腺癌の骨転移を 判定することを主たる目的に開発されてきた。一方, 乳癌では, 前立腺癌と同様の造骨性転移が少なからず 認められるものの,その大多数は溶骨性骨転移であり, 骨転移の存在診断ならびに治療効果の判定には, 骨吸 収マーカーの方が有用と考えられている，乳癌以外の 種々の固形癌も溶骨性骨転移の形態をとることが多 く, また骨粗影症の骨代謝判定にも, 骨吸収マーカー の測定が必須であることから，骨形成マーカーよりも 骨吸収マーカーが数多く開発されてきだ。

骨吸収マーカーの内，尿中八イドロキシプロリン (Hpr)は, コラーゲン代謝の10\%程度しか反映せず7), また酒石酸抵抗性酸ホスファターゼ (TRAP) は,コ ラーゲン代謝の反映程度の低さに加えて測定上の問題 点を種々有するため多, 現在臨床使用されることは稀 である.一方，コラーゲン架橋代謝物であるピリジノ リン (Pyr)やD-Pyr は，HprやTRAPよりも骨によ り特異的に存在するため, より高頻度に臨床使用され ている.

近年, 骨に対する特異性がより高い骨代謝マーカー として, 血中マーカーとしては I CTP, 尿中マーカー としてはNTx が開発され両マーカーとも現在非常に 注日を浴びている. I CTP は, Risteli ら゙が, NTx は, Eyre ら 1 がそれぞれ既存の骨吸収マーカーに較べ て骨に対する特異性が高いと報告している。一方, 骨 病変診断における I CTPと NTx の臨床比較は,これ までに殆どなされておらず，唯一, Garnero ら”が, 骨 粗鬆症でのビスホスホネート療法による骨量変化の予 測に扔いて, NTxがI CTPよりも優れていると報告 しているのみである.しかしながら, Garneroらのの報 告は担癌患者を対象としたものではなく，本報告が乳 癌骨転移患者を対象としてNTx およびI CTPの比 較を行った初報告と思われる。

今回の検討でも, 個々の骨代謝マーカーで報告され
ているごとく，NTx およびI CTPは，いずれも骨転 移個数が多くなる程高値を示したが I CTP の方が骨 転移個数とより良好な相関を示した。また骨転移陰性 例との比较では, I CTP は有意に, NTx は有意では ないものの骨枟移陽性例でより高值を示した。しかし ながら cut off 值を越える症例の割合は，I CTPが $56.7 \%$ 高值を示したのに対し，NTxは10\%台に留 まった.

今回の検討では，I CTPにおいて2例 (6.6\%)の 誤陽性例を認めた. NTxでは，誤陽性例を認めなかっ たことからすれば，NTxの方が優れた骨代謝マーカ 一である可能性も存在する。しかしながら㕵陽性例は, わずか 2 例のみであり，本研究では，骨転移陰性を骨 シンチ所見と疼痛の欠落所見のみから判断しているこ とからすれば，今後の観察で真陽性例と判明する可能 性も残されている。逆に真陽性率で見た場合, NTxで は骨病変の PD 症例が13例 (43\%)も含まれていたにも 関わらず,骨転移を認める症例においても cut off 值以 上を示す症例が20\%未満に留まった。

以上より, 今後, 症例数を増やして更に検討する必 要はあるものの乳癌骨転移診断においては，NTx よ りも I CTPの方が優れているものと思われる.

\section{文献}

1) Hanson DR, Weis MA, Bollen AM, et al:A specific immunoassay for monitoring human bone resorption:quantitation of type I collagen cross-linked $\mathrm{N}$-telopeptides in urine. J Bone Miner Res 7: 1251-1258, 1992

2) Rosen HN, Dresner-Pollak R, Moses AC, et al : Specificity of urinary cross-linked $\mathrm{N}$-telopeptides of type I collagen as a marker of bone turnover. Calcif Tissue Int $54: 26-29,1994$

3) Elomaa I, Virkkunen $P$, Risteli L, et al : Serum concentration of the cross-linked carboxyterminal telopeptide of type I collagen (I CTP) is a useful prognostic indicator in multiple myeloma. Br J Cancer 66 : 337-341, 1992

4) Risteli J, Elomaa I, Niemi S, et al: Radioimmunoassay for the pyridinoline cross-linked carboxy-terminal telopeptide of type I collagen: A new serum marker of bone collagen degeneration. Clin Chem 39:635-640, 1993

5）松本俊夫：骨代謝マーカー研究の現状と将来展 望. 福永仁夫, 中村利孝, 松本俊夫編集, 骨代謝 
マーカー, メデカルレビュー社, 東京, 1995, p 2 $-11$

6）福本誠二，松本俊夫：骨形成・骨吸収のシグナリ ングと骨粗箖症. 松本俊夫編集, 骨シグナルと骨 粗籍症. 羊土社, 東京, 1997, p12-17

7) 大西英生：骨吸収マーカー〜コラーゲン代謝物. 福永仁夫, 中村利孝, 松本俊夫編集, 骨代謝マー カー, メヂカルレビュー社, 東京, 1995, p84-93

8）中塚喜義, 西沢良記：骨吸収マーカー〜酒石酸抵
抗性酸ホスファターゼ. 福永仁夫, 中村利孝, 松 本俊夫編集, 骨代謝マーカー, メヂカルレビュー 社, 東京, 1995, p73-83

9) Garnero P, Shih WJ, Gineyts E, et al : Comparison of new biochemical markers of bone turnover in late postmenopausal osteoporotic women in response to alendronate treatment. J Clin Endocrinol Metab 79: 1693-1700, 1994

\section{EVALUATION OF BONE METASTASIS IN BREAST CANCER WITH TYPE I COLLAGEN CROSS-LINKED N-TELOPEPTIDE AND TYPE I COLLAGEN CROSS-LINKED C-TELOPEPTIDE}

\section{Shoji OURA and Yasuaki NAITO}

Department of Thoracic and Cardiovascular Surgery, Wakayama Medical College

Diagnostic ability of type I collagen cross-linked N-telopeptide (NTx) against bone metastasis or bone invasion of breast cancer was evaluated in comparison with type I collagen cross-linked C-telopeptide (I CTP). Subjects were 30 female patients with breast cancer having bone metastasis or bone invasion. As the number of bone lesions increased, both NTx and I CTP levels increased. Levels of I CTP correlated better to the number of bone metastatic foci than those of NTx. Each biochemical marker showed higher levels in patients with bone metastasis than in those without bone lesions. Ratios of the patients with above the cut-off level of the biochemical marker were $16.7 \%$ in NTx and $56.7 \%$ in I CTP. Patients with poorly controlled bone metastasis showed twice the levels than those with well controlled lesions in I CTP, and 1.7-fold the levels in NTx. However, the average of the NTx was smaller than the cut off level even in patients with progressive bone metastasis. In conclusion, I CTP is a more useful biochemical marker than NTx in the diagnosis of bone metastasis in breast cancer. 